\title{
An Investigation About Actualization Levels of Learning Outcomes in Early Childhood Curriculum
}

\author{
İbrahim Yaşar Kazu ${ }^{1}$, Abdulgafur İş² \\ ${ }^{1}$ Frrat University, Department of Educational Sciences, Elazıg, Turkey \\ ${ }^{2}$ Sirnak University, Cizre Vocational College, Child Development, Sirnak, Turkey \\ Correspondence: İbrahim Yaşar Kazu, Furat University, Department of Educational Sciences, Elazıg, Turkey.
}

Received: January 15, 2018

Accepted: January 31, $2018 \quad$ Online Published: February 15, 2018

doi:10.11114/jets.v6i3.2928

URL: https://doi.org/10.11114/jets.v6i3.2928

\begin{abstract}
Understanding the characteristics of preschool-age children is an important and first step for supporting children's healthy development and school readiness. Children may show different developmental features and come different social, socio-cultural background; however, they are in the same age. Reaching of education at a desired level will be achieved by a good curriculum which is organized and put in practice. Therefore, the curriculum should be organized by considering all students' features. Therefore, the curriculum should be practicable and related with the needs of today's world and social expectation for a good early childhood education programs. Accordingly, it is aimed to investigate the actualization levels of learning out comes related to developmental areas in early childhood education curriculum. Working group of the research is composed of 165 primary school teachers and 136 pre-school teachers working in districts and Centre of Sirnak, Turkey. Scanning method was used in the study. Two different questionnaires were prepared related with developmental areas of early childhood and the data was obtained through a questionnaires and analysed in SPSS package program. Questionnaires have two parts. In first part, there is personal information about teachers and in the other part there are statements about out-comes of developmental areas in the Early Childhood Curriculum. According to the results, the pre-school teachers gave a high score to the questionnaire by stating positive opinion towards the pre-school curriculum sufficiency and achievement. In addition, primary teachers gave lower scores on the questionnaire that the children achieved out comes. As a result, significant differences were found between pre-school and primary school teachers' views on all areas of development.
\end{abstract}

Keywords: pre-school curriculum, language development, cognitive development, social development, psychomotor development, self-care skills

\section{Introduction}

Education is an important factor both for the day-to-day development of the child and for contributing to the personal, social, cultural and economic fulfillment of the future adult. Internationally, there is a growing need for quality in early childhood care and education as greater numbers of families migrate to urban areas and more mothers enter the workforce. However, the curriculum available for young children vary greatly in quality. A number of reports have stressed the undeniable link between quality of caregiving and young children's survival and health (United Nations Educational, Scientific and Cultural Organization (UNESCO) 2006) as well as their social, emotional, cognitive, language, and physical development. When one's whole life is thought, it is known that some life spans should be considered as critical periods in terms of psychological and physiological developments. It is stressed by many educators that the period between the age of $0-6$, which includes pre-school education, is a critical period for development of children. For instance, the pre-school years which include the ages of 0-6 are one of the most critical periods of life with the influence of formation of the personality, the acquisition of basic knowledge, skills and habits in the following years. The main force is the basic knowledge, skills and habits that will be gained through early childhood experiences that will shape the child's future learning as well as his social and emotional life. The pre-school education, which should be conducted by a scientific and systematic organization, is the most crucial step of the whole education system, because of this importance, this period can not be left up to chance.

The term Early Childhood Development (ECD) usually refers to the process of development during the early childhood period, which many professional organisations consider as lasting from birth to eight years old although other 
stakeholders consider that the early childhood period lasts from birth to primary-school entry, which is six or seven years old in most countries (Rao, et al., 2014).

Early education affects the academic success of the child in following years, as well as the developmental areas (cognitive, social, language, psychomotor and self-care) in a positive way. School readiness consists of social-emotional competencies as well as other cognitive and motivational competencies required for success in school (Abbott, Lundin, \& Ong, 2008). It can be defined as the developmental milestones achieved by children across multiple domains in the early years of life. This study reviews each domain (cognitive development, fine and gross motor development, socialemotional development, language development) separately to define and describe significant achievements in each area. Cognitive development refers to the progressive and continuous growth of perception, memory, imagination, conception, judgment, and reason; it is the intellectual counterpart of one's biological adaptation to the environment. (Nicolasi, Harryman \& Kresheck, 1989). Cognition also involves the mental activities of comprehending information and the processes of acquisition, organizing, remembering, and using knowledge (Owens, 2008). This knowledge is subsequently used for problem solving and generalization to novel situations. Cognitive development refers to advances in mental processes associated with perception, memory, reasoning, problem-solving, language-learning and other aspects of brain development that occur with increasing age (Rao, et al., 2014).

When we talk about the motor development, we usually consider gross motor and fine motor skills. Gross motor skills refers to movements involving large muscles, such as trunk muscles used for sitting upright and leg muscles used for walking. Smaller muscles, such as those in the fingers or tongue, are used for fine motor tasks, such as writing and talking, respectively (Shulman and Singleton, 2010).

The physical stimulation is critical for childhood development (Timmons, Naylor \& Pfeiffer, 2007; Trudeau \& Shephard, 2008). It is through motor exploration that children's self-awareness and awareness of the outside world arises. The progressive acquisition of skills concerning both mental and motor activities is defined as psychomotor development. Therefore an active lifestyle during childhood is beneficial to physical, cognitive, and mental health (Chaddock-Heyman et al., 2013; Chaddock, 2012; Tomporowski, Davis, Miller \& Niglieri, 2008). Motor experiences are vital conditions for adaptation in a child's didactic learning; and can stimulate thinking. Additionally, a poor field of operation can delay and limit an individual's perceptive abilities (Thompson, 1996).

It is widely recognised that the child's social and emotional development significantly influences his or her success in learning. Social- emotional development in children is mostly evaluated by psychologists and teachers. A child must be interested in socializing and communicating with others to be an effective communicator. In early infancy, we are most concerned with a child's connectedness with his world. This connectedness is initially expressed through nonverbal modes, such as eye contact and facial expressions. Infants have a preference for faces, and it is through this preference that they establish the foundation for early social relationships with others. Children establish imitation skills by studying others in their environment. This practice begins as imitation of facial expressions (such as smiles) and then develops into imitation of more complex behaviors, such as actions on objects (e.g., throwing a ball, emptying a container), specific motor patterns (e.g., clapping, dancing), and eventually speech and language development. A strong social-emotional foundation is a key to the development of verbal language behavior (Shulman and Singleton, 2010).

Many stages of language acquisition, children seem to be experimenting with new means of linguistic expression; for example, they may begin to use more complicated forms of syntax. A similar process has been observed for lexical development (Brown, 1973). Research by Bloom, Lightbown, and Hood (1974) illustrates an additional advantage in learning that young children may have as a result of their relative flexibility to select tasks and goals. Young children have the opportunity to "choose" the domains within which they can develop new knowledge and skills. For example, Bloom et a1. (1974) studied the development of children's linguistic abilities.

Bloom and Tinker (2001) have proposed a three component model of language development, termed the intentionality model, which emphasizes the impact of engagement (social and emotional development) and effort (cognitive development) in the process of language acquisition. In this model, the child's responsiveness to the environment, and his social connectedness to others, establishes for the child what is relevant to learn and what the motivation to learn is. The concept of cognitive effort concerns the work that is required in actively learning about the world. A child must be socially connected to the world and motivated to learn more about the world to figure out how to communicate with others. Thus the intentionality model brings together the components of cognition and social-emotional development and unites them with language in a clear way.

Toward the end of the century when perceptions became more globalized, there was a growing awareness of preschool programs in many countries. More importantly, interest was growing about the nature of these programs and developing countries trying to begin programs were seeking guidance on how to evaluate the quality of their programs.

Curriculum refers to the learning experiences and routines that make up the day in the preschool classroom. It is a plan 
that reflects the philosophy and culture of the area or country. The curriculum is child-centered and stems from the belief that children are competent. The curriculum focuses on the whole child and includes all categories of development (ACEI 2006, p.8). Pre-school curriculum enables children to become ready for primary school by influencing their development in a positive way. In a qualified pre-school curriculum, communication between teacher-child and child-child continues during day with an interaction with mutual listening, question-answer, reasoning and problem solving. They often interact with peers and teachers; they can not spend time by waiting, neglecting or being isolated from class. They love the school and really enjoy going to school. During the day, it is included that children benefit from the opportunities of art, music, science, mathematics, play, movement, drama, and there are various activities for the adoption of diversity and reinforce learning, and the curriculum encourages the family involvement in all aspects. (Espinosa, 2002: 3). Parents are the child's primary educators, and the life of the home is the most effective factor in his or her development during the primary school years. Close co-operation between the home and the school is essential, if children are to receive the maximum benefit from the curriculum.

As most of the development of the individual is completed between 0 and 6 ages, this period should be emphasized. Pre-school education, which is considered as early childhood period, includes the childhood years from birth to the beginning of primary school. Pre-school education was defined as a training process that best guided their physical, social, emotional, language and mental development in the best way in terms of the cultural values and characteristics of the society, and as a process providing a rich stimulating environment suitable for the individual characteristics and developmental levels of children in this age group (Oğuzkan and Oral, 1997: 2). Reaching of education at a desired level will take place through the implementation of a good curriculum that will be put in practice. In this regards, it should be clear that the curriculum applied in the realization of a good pre-primary education must be feasible and developed to meet today's needs and social expectations and also it should be open to be developed. The evaluation step in the development of the curriculum has great importance. It will be possible to identify the difficulties encountered during the putting in practice step and to develop the curriculum on the basis of the feedbacks and evaluations. The first five years of life is also very important for the future development of the child. There is remarkable growth in children during this development period, but the importance of supporting the development of children in cognitive, social, emotional and motor development areas is not emphasized sufficiently (Kachmar, 2008:30). Accordingly, it is aimed to investigate of actualization levels of learning out comes related to developmental areas. Due to the inadequate works related to the topic; it is considered that the research will be beneficial for the teachers who are the practitioners of the curriculum and for the curriculum preparation studies.

\section{Method}

The scanning method was used in the study. Questionnaires were prepared by the researcher regarding the development areas in the pre-school curriculum. The questionnaire consists of two parts; there are personal questions about the participants in the first part and there are questions about the developmental areas in the second part. Options are arranged as always, often, occasionally, almost never and never. The data of the questionnaire applied to measure the development areas in the pre-school curriculum were analyzed and uploaded to the computer SPSS package program. The information about the score ranges of the survey items is given in table below.

Table 1. The information about the score ranges of the survey items

\begin{tabular}{lc}
\hline Level of Participant & Item Ranges \\
\hline Never & $1,00-1,80$ \\
\hline Almost never & $1,81-2,60$ \\
\hline Occasionally & $2,61-3,40$ \\
\hline Often & $3,41-4,20$ \\
\hline Always & $4,21-5,00$ \\
\hline
\end{tabular}

The questionnaire were formed from the items related to the developmental areas in order to determine the actualization levels of learning out comes related to developmental areas in pre-school curriculum in the direction of the teachers' opinions and there are five of likert types (Always $=5$, Often $=4$, Occasional $=3, \quad$ Almost never $=2$, never $=1$ ).

\section{Findings}

The personal information and graduation fields of the participants, which are related with quantitative dimension of the study, are given below separately.

Table 2. Information about graduation fields of the participants

\begin{tabular}{lll}
\hline Group & $\mathbf{n}$ & $\mathbf{( \% )}$ \\
\hline Pre-school Teacher & 136 & 45,2 \\
\hline Primary school Teacher & 165 & 54,8 \\
\hline Total & 301 & 100,0 \\
\hline
\end{tabular}


In the study, there were 136 pre-school teachers $(45,2 \%), 165$ primary school teachers $(54,8 \%)$ and in total there were 301 participants.

Table 3. Information about answers given by pre-school teachers about language development

\begin{tabular}{|c|c|c|c|c|c|}
\hline NO & ITEMS & f & $\%$ & $\bar{x}$ & SS \\
\hline 1 & $\begin{array}{l}\text { I prepare activities that will enable them to speak Turkish language by using the correct } \\
\text { grammatical rules. }\end{array}$ & 118 & 86,4 & 4,32 & ,403 \\
\hline 2 & I include activities that improve children's vocabulary. & 120 & 88,6 & 4,43 & ,409 \\
\hline 3 & I pay attention to explain the child's feelings and thoughts about a topic or situation. & 126 & 92,4 & 4,62 & ,397 \\
\hline 4 & for children to use the language correctly in the c & 127 & 93,6 & 4,68 &, 382 \\
\hline 5 & dio activities for children (using different voices, recognizing). & 110 & 80,8 & 4,04 & ,404 \\
\hline 6 & I pay attention to family involvement in effective use of language. & 108 & 79,2 & 3,96 & 400 \\
\hline 7 & $\begin{array}{l}\text { I include the activities that contribute to make them understand the awareness of sound } \\
\text { knowledge. }\end{array}$ & 109 & 80,2 & 4,01 & ,418 \\
\hline 8 & I include activities that will make them be aware of reading awarene & 112 & 82,2 & 4,11 & ,404 \\
\hline 9 & tivities to help them read visual materials. & 118 & 86,4 & 4,32 & ,403 \\
\hline 10 & $\begin{array}{l}\text { I offer opportunities to children to express the topics, which they listen and watch, in different } \\
\text { ways. }\end{array}$ & 120 & 88 & 4,40 & ,409 \\
\hline
\end{tabular}

There is statistical information about the answers given by the pre-school teachers to the questions asked about the achievements in the curriculum related to language development in the table above. When the table is examined, it is seen that most of the teachers have given high rates to almost all the questions. Besides, there are items in which all participants are nearly agree such as expressing emotions and thoughts $(\bar{X}=4,62)$, being a good model of teachers in development of language skill ( $\bar{X}=4,68)$ and preparing activities to improve vocabulary $(\bar{X}=4,43)$. We can say that the item which has the least attendance intensity related to language development of pay attention to family participation in using language effectively ( $\bar{X}=3,96$ ).

Table 4. Information about answers given by classroom teacher about language development

\begin{tabular}{|c|c|c|c|c|c|}
\hline No & ITEMS & f & $\%$ & $\mathrm{X}$ & SS \\
\hline 1 & They are using Turkish grammatically correct. & 107 & 64,8 & 3,24 & ,603 \\
\hline 2 & Children's vocabulary is at expected level according to their age. & 105 & 63,4 & 3,17 &, 587 \\
\hline 3 & They can sufficiently express their feelings and thoughts about a subject or situation. & 113 & 68,2 & 3,41 &, 643 \\
\hline 4 & They use Turkish in the class correctly and effectively. & 108 & 65,4 & 3,27 &, 612 \\
\hline 5 & Children are successful in some areas such as making different sour & 119 & 72 & 3,60 &, 583 \\
\hline 6 & Families pay attention to sensitivity and effective use of language. & 91 & 55,4 & 2,77 & 634 \\
\hline 7 & They can produce words that start or end with the same voice. & 105 & 63,4 & 3,17 &, 527 \\
\hline 8 & f reading and writing in daily life. & 113 & 68,6 & 3,43 &, 615 \\
\hline 9 & Children can create stories using visual materials. & 101 & 61 & 3,05 & 603 \\
\hline 10 & Children can express the context, which they listen or watch, in different ways. & 112 & 67,8 & 3,39 &, 584 \\
\hline
\end{tabular}

In the table above, there is statistical information about the answers given by the primary school teacher to the questions asked about the achievements in the curriculum related to language development in their classes. When evaluating the average values, it is seen that pre-school teachers' responses to all the items related to language development achievements are higher than the responses of the primary school teacher. However, when evaluating the lowest grades of the primary school teacher it can be said that families show the necessary sensitivity to language $(\bar{X}=2,77)$, word back formation and visual materials $(\bar{x}=3,05)$. It can be also said that students are successful in expressing different sounds ( $\bar{X}=3,60)$, speaking Turkish language grammatically correct $(\bar{x}=3,24)$.

Table 5. Information about answers given by pre-school teachers about cognitive development

\begin{tabular}{|c|c|c|c|c|c|}
\hline NO & ITEMS & f & $\%$ & $\mathrm{X}$ & SS \\
\hline 1 & $\begin{array}{l}\text { I try to make students acquire the skills such as grouping / classification and matching by using } \\
\text { various activities. }\end{array}$ & 119 & 87,6 & 4,38 & ,433 \\
\hline 2 & I encourage students to be interested in the object / situation and case. & 120 & 88,4 & 4,42 & 425 \\
\hline 3 & I offer a variety of tips to help them remember their perception and what they learn. & 120 & 88 & 4,40 & ,429 \\
\hline 4 & I offer opportunities for students to observe the objects or assets. & 119 & 87,6 & 4,38 & ,433 \\
\hline 5 & I include activities that will enable them to count forward and backward rhythmically. & 115 & 84,2 & 4,21 & ,436 \\
\hline 6 & $\begin{array}{l}\text { I prepare various activities related to the position in space and apply them for students } \\
\text { understanding. }\end{array}$ & 113 & 83,4 & 4,17 & ,445 \\
\hline 7 & I make students perform simple addition and subtraction by using objects & 102 & 75,2 & 3,76 & ,468 \\
\hline 8 & I include activities that will enable them to identify symbols used in everyday life. & 114 & 83,6 & 4,18 & ,458 \\
\hline 9 & I offer opportunities for students to solve problem status. & 113 & 83,4 & 4,17 & ,446 \\
\hline 10 & I offer activities that will help them make contact between cause and result. & 115 & 84,2 & 4,21 & ,436 \\
\hline
\end{tabular}


On the table 5, there is statistical information about the answers given by the pre-school teachers to the questions asked about the achievements in the curriculum related to cognitive development. When the table is examined, it is seen that most of the teachers gave high scores to almost all the questions. We can say that pre-school teachers are more involved in the items, which are paying attention to a situation or a case $(\bar{X}=4,38)$, sorting-matching, remembering what they see $(=4,38)$, than other items. In addition, we can say that the least participatory view is to make students perform mathematical operations such as simple addition and subtraction related to cognitive development ( $\bar{X}=3,76$ ).

Table 6. Information about answers given by primary school teachers to cognitive development

\begin{tabular}{|c|c|c|c|c|c|}
\hline NO & ITEMS & f & $\%$ & $\bar{x}$ & SS \\
\hline $\mathbf{1}$ & $\begin{array}{l}\text { Children can perform activities that require grouping / sorting and matching } \\
\text { skills. }\end{array}$ & 112 & 67,6 & 3,38 & ,658 \\
\hline 2 & They pay attention to the object / situation and case. & 118 & 71,8 & 3,59 & ,637 \\
\hline 3 & They can remember what they perceive and learn. & 121 & 73,6 & 3,68 &, 597 \\
\hline 4 & Children can carefully observe and examine objects or events. & 118 & 71,6 & 3,58 & 625 \\
\hline 5 & They can count forward and backward rhythmically. & 123 & 74,6 & 3,73 & 642 \\
\hline 6 & They have enough information about the position in space. & 114 & 68,8 & 3,44 & 667 \\
\hline 7 & Students can do simple addition and subtraction. & 118 & 71,6 & 3,58 & 632 \\
\hline 8 & Students know the symbols used in everyday life. & 115 & 69,4 & 3,47 & 644 \\
\hline 9 & They can produce solutions to their problems. & 106 & 64,2 & 3,21 & 602 \\
\hline 10 & They can establish cause and effect relationships between events and situations. & 108 & 65,2 & 3,26 & 612 \\
\hline
\end{tabular}

There is statistical information about the answers given by the primary school teachers to the questions asked about the level of achievements in the curriculum related to cognitive development in the table above. When looking at the mean values, it is seen that pre-school teachers' responses to all the items related to cognitive development gains are higher than the answers of the primary school teachers. It is seen that there is an intense participant view about success in counting forward and backward numbers $(\bar{X}=3,73)$, remembering what they perceive and learn $(\bar{X}=3,68)$. We can say that the lowest scores are given to the items of producing solutions to the problem situations $(\bar{X}=3.21)$ and making a relationship between cause and result ( $\bar{X}=3.26$ ).

It is widely recognized that the student's social and emotional development significantly influences his or her success in learning. This is addressed most effectively through a school environment that is characterised by a caring, interactive relationship between teachers and pupils. It is also a central concern of learning in every curriculum area. Its importance is stressed, through social, personal and health education. By providing students with a successful and happy school experience, by nurturing essential intrapersonal and interpersonal development, and developing communication skills, children's self-esteem and self-confidence can be developed and their motivation to learn can be increased (Martin, 1999).

Table 7. Information about answers given by pre-school teachers to social development

\begin{tabular}{|c|c|c|c|c|c|}
\hline NO & ITEMS & f & $\%$ & $\overline{\bar{x}}$ & SS \\
\hline 1 & I include activities that will help them understand others' feelings. & 116 & 85,6 & 4,28 & ,475 \\
\hline 2 & I prepare environments to be aware of differences and to respect them. & 115 & 84,2 & 4,21 & ,432 \\
\hline 3 & I prepare activities which enable them to protect their and others' rights. & 112 & 84 & 4,12 & ,496 \\
\hline 4 & I do my best effort to make them responsible individuals. & 123 & 90,8 & 4,54 & ,489 \\
\hline 5 & $\begin{array}{l}\text { I prepare various activities (sightseeing / observation) for obeying the rules in different } \\
\text { environments. }\end{array}$ & 101 & 74 & 3,70 &, 503 \\
\hline 6 & I include activities that will enable them to recognize different cultural features. & 99 & 72,6 & 3,63 &, 586 \\
\hline 7 & I offer a variety of activities which help protect aesthetic values. & 106 & 77,6 & 3,88 &, 549 \\
\hline 8 & I offer activities that contribute children to have self-confidence. & 122 & 90 & 4,50 & ,462 \\
\hline 9 & I motivate children to work together in the group. & 124 & 91,4 & 4,57 &, 446 \\
\hline
\end{tabular}

There is statistical information about the answers given by the pre-school teachers to the questions asked about the level of achievements in the curriculum related to social development in the table above. When the table is examined, it is seen that most of the teachers gave high score to almost all the questions. We can say that the items, which have the highest participant views, are making them gain self-confident $(=4.50)$, cooperating with the group and taking responsibility ( $\bar{X}=4,57)$; the items like introducing different cultures $(\bar{X}=3,63)$, making trip observations $(\bar{X}=3,70)$ and gaining aesthetic skills have lowest participant views.

The curriculum acknowledges that children live in and are a part of society, and that their personal development is deeply affected by their relationships in the home and with other people in society. We have come to understand children's characteristics and developmental needs from the perspective of child development psychology, as well as from the contexts of their families and social culture (The Hong Kong Special Administrative Region Government, 2006). 
Table 8 . Information about answers given by primary school teachers to social development

\begin{tabular}{|c|c|c|c|c|c|}
\hline NO & ITEMS & f & $\%$ & $X$ & SS \\
\hline $\mathbf{1}$ & They can understand others' emotions by empathizing with them. & 107 & 65 & 3,25 &, 632 \\
\hline 2 & They know that they need to be aware of differences and respect those differences. & 109 & 66,2 & 3,31 & ,642 \\
\hline 3 & They are careful to protect the rights of their own and others. & 110 & 66,6 & 3,33 &, 632 \\
\hline 4 & They give importance to fulfill their responsibilities. & 119 & 72,2 & 3,61 &, 645 \\
\hline 5 & They obey the rules that they are supposed to obey in different environments. & 116 & 70,6 & 3,53 &, 669 \\
\hline 6 & They recognize different cultural features and respect these differences. & 107 & 64,8 & 3,24 &, 632 \\
\hline 7 & They are aware of their aesthetic values and have a consciousness for protecting them. & 103 & 62,6 & 3,13 &, 652 \\
\hline 8 & They have self-confidence. & 123 & 74,6 & 3,73 &, 624 \\
\hline 9 & They show the necessary sensitivity to cooperation with the group. & 116 & 70,6 & 3,53 & ,668 \\
\hline
\end{tabular}

There is statistical information about the answers given by the pre-school teachers to the questions asked about the level of achievements of the social development of the children who benefit from the pre-school curriculum in their class. When the average values are examined, it is seen that pre-school teachers' responses to all the items related to social development achievements are higher than the responses of the primary school teacher. While the teachers agree on the items such as having confidence in social development $(\bar{X}=3,73)$, being aware of responsibility $(\bar{X}=3,61)$, and obeying the rules $(\bar{X}=3,53)$, the expressed lower scores on the items like aesthetic skills $(\bar{X}=3,13)$, recognizing different cultures $(\bar{X}=3,24)$ and empathy skills $(\bar{X}=3.25)$.

Table 9. Information about the answers given by pre-school teachers to psychomotor development

\begin{tabular}{|c|c|c|c|c|c|}
\hline NO & ITEMS & $\mathbf{f}$ & $\%$ & $\overline{\mathbf{x}}$ & SS \\
\hline 1 & I offer activities that support children's gross motor skills. & 124 & 91,4 & 4,57 & 425 \\
\hline 2 & I prepare activities that will enable them to do the necessary movements of object control. & 118 & 87 & 4,35 & ,442 \\
\hline 3 & I choose the activities that are most appropriate for the actions that require balance. & 115 & 84,6 & 4,23 & 422 \\
\hline 4 & I frequently include activities that they could accompany music and rhythm. & 114 & 84 & 4,20 & 455 \\
\hline 5 & $\begin{array}{l}\text { I pay attention to organize activities that will enable them to use different parts of their body } \\
\text { effectively. }\end{array}$ & 113 & 83 & 4,15 & 465 \\
\hline 6 & I offer activities that support children's fine motor skills. & 120 & 88,6 & 4,43 & ,421 \\
\hline 7 & I pay attention to prepare the games that require children to control. & 116 & 85,4 & 4,27 & ,433 \\
\hline 8 & $\begin{array}{l}\text { I pay attention to play games in their environments that need to be played (classroom, garden hall, } \\
\text { etc.). }\end{array}$ & 122 & 89,8 & 4,49 & ,414 \\
\hline 9 & I often involve the activities needing hand-eye coordination. & 124 & 91,2 & 4,56 & ,412 \\
\hline 10 & I pay attention to arrange the class so that it does not physically harm the child. & 126 & 92,4 & 4,62 & 407 \\
\hline
\end{tabular}

In the table above, there is statistical information about the answers given by the pre-school teachers to the questions asked about the level of achievements of the psychomotor development of the children who benefit from the pre-school curriculum in their class. When the table is examined, it is seen that most of the teachers gave high level answers to almost all the questions. When we look at the items, we can say that the most participatory views are the items which are the development of gross and fine motor skills $(\bar{x}=4,57-4,43)$, providing of hand-eye coordination $(=4,56)$ and the regulation of education areas $(\bar{X}=4,62)$.It is seen that the items that are least marked by the participants are related to the studies that require balance $(\bar{X}=4,15)$.

Table 10. Information about the answers given by primary school teachers to psychomotor development

\begin{tabular}{|c|c|c|c|c|c|}
\hline NO & ITEMS & $\mathbf{f}$ & $\%$ & $\bar{X}$ & SS \\
\hline 1 & Children succeed in using gross motor skills. & 126 & 76,4 & 3,82 &, 572 \\
\hline 2 & They can make the necessary movements of object control without difficulty. & 123 & 74,4 & 3,72 &, 585 \\
\hline 3 & They can make the movements that require balance without difficulty. & 123 & 74,4 & 3,72 &, 585 \\
\hline 4 & They can move in harmony with music and rhythm. & 124 & 75 & 3,75 &, 576 \\
\hline 5 & They can effectively use different parts of their body. & 123 & 74,6 & 3,73 &, 596 \\
\hline 6 & They succeed in using fine motor skills. & 114 & 68,8 & 3,44 & ,608 \\
\hline 7 & Children can play games required balance without difficulty. & 118 & 71,6 & 3,58 & ,613 \\
\hline 8 & They can play the games in their environments (classroom, garden hall, etc.). & 125 & 76 & 3,80 &, 559 \\
\hline 9 & They can do the activities needing hand-eye coordination easily. & 122 & 74,2 & 3,71 &, 563 \\
\hline 10 & They can use the materials in the class clearly in accordance with the classroom rules. & 121 & 73,2 & 3,66 &, 583 \\
\hline
\end{tabular}

In the table above, there is statistical information about the answers given by the classroom teachers to the questions asked about the level of achievements of the psychomotor development of the children who benefit from the pre-school curriculum in their class. When looking at the mean values, it is seen that pre-school teachers' responses to all the items related to psychomotor development gains are higher than the responses of the classroom teachers. We can say that the 
highest scores are given to the items which are that children are successful in using gross motor skills $(\bar{X}=3.82)$ and plays $(\bar{X}=3.80)$. It is seen that the lowest scores are given to the items which are that they are successful in using fine motor skills $(\bar{X}=3,44)$ and Children can play games requiring balance without difficulty. ( $\bar{X}=3,58$ )

Table 11. Information about the answers given by pre-school teachers to self-care skills

\begin{tabular}{llcccc}
\hline NO & ITEMS & $\mathbf{f}$ & $\mathbf{\%}$ & $\overline{\mathbf{X}}$ & $\mathbf{S S}$ \\
\hline $\mathbf{1}$ & I prepare and carry out various activities related to body health and hygiene for children. & 122 & 89,8 & 4,49 &, 435 \\
$\mathbf{2}$ & I pay attention to include activities to understand the importance of environmental hygiene. & 123 & 90,6 & 4,53 &, 423 \\
$\mathbf{3}$ & I cooperate with families for healthy and balanced nutrition. & 117 & 86 & 4,30 &, 463 \\
$\mathbf{4}$ & I try to be a model for children how to use the cooking utensils while eating with the children. & 116 & 85,6 & 4,28 &, 478 \\
$\mathbf{5}$ & I support the child in putting on his clothes on his own. & 123 & 90,8 & 4,54 &, 422 \\
$\mathbf{6}$ & I pay attention to cooperate with school staff at school and classroom hygiene. & 119 & 87,4 & 4,37 &, 451 \\
$\mathbf{7}$ & I do my best for them to keep the personal belongings at school in a regular basis. & 126 & 93 & 4,65 &, 413 \\
\hline
\end{tabular}

In the table above, there is statistical information about the answers given by the classroom teachers to the questions asked about the level of achievements of the self-care skills of the children who benefit from the pre-school curriculum in their class. When the table is examined, it is seen that most of the teachers gave high level answers to almost all the questions When we look at the items most marked by the participants, we can say that they are the items about keeping and using the items regularly ( $\bar{X}=4.65)$, removing clothes and wearing $(\bar{X}=4,54)$, and giving importance to environmental hygiene $(\bar{X}=4,53)$. We can say that the least marked items are cooperation with the family $(\bar{X}=4,30)$ and being a role model of eating ( $\bar{X}=4,28)$.

Table 12. Information about the answers given by primary school teachers to self-care skills

\begin{tabular}{|c|c|c|c|c|c|}
\hline NO & ITEMS & $\mathbf{f}$ & $\%$ & $\bar{x}$ & SS \\
\hline 1 & Children have enough knowledge of body health and hygiene. & 119 & 72 & 3,60 & ,762 \\
\hline 2 & They are aware of the importance of environmental hygiene and show the necessary importance to this. & 114 & 69,2 & 3,46 & ,799 \\
\hline 3 & They show great interest in healthy and balanced nutrition. & 112 & 67,8 & 3,39 & ,792 \\
\hline 4 & Children are able to use their eating utensils appropriately. & 118 & 71,4 & 3,57 & ,785 \\
\hline 5 & They are dressed according to seasonal conditions and care for hygiene of clothes. & 118 & 71,4 & 3,57 & ,785 \\
\hline 6 & They show the sensitivity for school and classroom hygiene. & 117 & 70,8 & 3,54 & ,772 \\
\hline 7 & $\begin{array}{l}\text { They have the awareness that they need to use and keep the personal items of the school regularly and share them } \\
\text { with friends whenever necessary. }\end{array}$ & 120 & 72,8 & 3,64 & ,746 \\
\hline
\end{tabular}

In the table above, there is statistical information about the answers given by the classroom teachers to the questions asked about the level of achievements of the self-care skills of the children who benefit from the pre-school curriculum in their class. When looking at the mean values, it is seen that pre-school teachers' responses to all the items related to self-care skills gains are higher than the responses of the primary school teachers. We can say that the highest scores are given to the items about personal hygiene and care for using personal items ( $\bar{X}=3.64)$. It is seen that the lowest scores are given to the item of being aware of the importance of healthy and balanced nutrition ( $\bar{X}=3.39)$.

The minimum, maximum scores, average and standard deviation values given by participants to the items in the questionnaire about area of development and the results of these answers are presented below in the table.

Table 13. Information on the minimum and maximum scores of the answers given by the teachers in the questionnaire

\begin{tabular}{lllllll}
\hline \multirow{2}{*}{ Zone of development } & Group & $\mathbf{f}$ & Min & Max & $\bar{X}$ & \multirow{2}{*}{ SS } \\
& & & & & & \\
\hline \multirow{2}{*}{ Language Development } & Pre School & 136 & 3,00 & 5,00 & 4,28 &, 403 \\
\cline { 2 - 7 } & Primary school & 165 & 1,50 & 5,00 & 3,24 &, 603 \\
\hline \multirow{2}{*}{ Cognitive Development } & Pre School & 136 & 3,00 & 5,00 & 4,22 &, 443 \\
\cline { 2 - 7 } & Primary school & 165 & 1,80 & 4,70 & 3,49 &, 527 \\
\hline \multirow{2}{*}{ Social Development } & Pre School & 136 & 2,78 & 5,00 & 4,15 &, 494 \\
\cline { 2 - 7 } & Primary school & 165 & 1,56 & 5,00 & 3,40 &, 646 \\
\hline \multirow{2}{*}{ Psychomotor Development } & Pre School & 136 & 2,80 & 5,00 & 4,38 &, 435 \\
\cline { 2 - 7 } & Primary school & 165 & 1,44 & 5,00 & 3,69 &, 580 \\
\hline \multirow{2}{*}{ Self-Care Skills } & Pre School & 136 & 2,57 & 5,00 & 4,45 &, 449 \\
\cline { 2 - 7 } & Primary school & 165 & 1,43 & 5,00 & 3,53 &, 771 \\
\hline
\end{tabular}


The table above contains statistical information related to the implementation of the pre-school curriculum and the level of learning outcomes. When looking at average values, pre-school teachers' perceptions of how to prepare and apply the activities to achieve outcomes in their developmental areas seem to be at a higher level than the gains that primary school teachers observed in these children. In general, when answers of participants to developmental areas are examined, it is observed that the preschool teachers in all areas of development gave higher scores than primary school teachers.

Below there is a table of the results of the $t$ test, indicating whether there is a difference in areas of development in terms of pre-school and classroom teachers and if there is a difference, this table shows us the significance value of the difference.

Table 14. t-test which shows whether the views on gains for development areas differ pre-school teachers from primary school teachers

\begin{tabular}{|c|c|c|c|c|c|c|c|}
\hline Zones of Development & Group & $\mathbf{f}$ & $\bar{x}$ & $\mathbf{S S}$ & $\mathbf{t}$ & & $\mathbf{P}$ \\
\hline \multirow[b]{2}{*}{ Language Development } & Pre School & 136 & 4,28 & ,403 & \multirow[b]{2}{*}{17,180} & \multirow[b]{2}{*}{,000 } & \\
\hline & Primary school & 165 & 3,24 & ,603 & & & \\
\hline \multirow[b]{2}{*}{ Cognitive Development } & Pre School & 136 & 4,22 & ,443 & \multirow[b]{2}{*}{12,921} & \multirow[b]{2}{*}{, 000} & \\
\hline & Primary school & 165 & 3,49 &, 527 & & & \\
\hline \multirow[b]{2}{*}{ Social Development } & Pre School & 136 & 4,15 & ,494 & \multirow[b]{2}{*}{11,117} & \multirow[b]{2}{*}{, 000} & \\
\hline & Primary school & 165 & 3,40 & ,646 & & & \\
\hline \multirow[b]{2}{*}{ Psychomotor Development } & Pre School & 136 & 4,38 & ,435 & \multirow[b]{2}{*}{11,503} & \multirow[b]{2}{*}{, 000} & \\
\hline & Primary school & 165 & 3,69 &, 580 & & & \\
\hline \multirow[b]{2}{*}{ Self-Care Skills } & Pre School & 136 & 4,45 & 449 & \multirow[b]{2}{*}{12,189} & \multirow[b]{2}{*}{, 000} & \\
\hline & Primary school & 165 & 3,53 & ,771 & & & \\
\hline
\end{tabular}

The thoughts of pre-school teachers' on plans and practices to perform gains in the language development curriculum $(4,28)$ are higher than primary school teachers' thoughts of children achieving these gains $(3,24)$. As the significance value is $\mathrm{p}=0,000<0,05$, there is a significant difference between primary school teachers and pre-school teachers in favour of pre-school teachers' regarding language development gains.

The thoughts of pre-school teachers' on plans and practices to perform gains in the cognitive development curriculum $(4,22)$ are higher than primary school teachers' thoughts of children achieving these gains $(3,49)$.As the significance value is $\mathrm{p}=0,000<0,05$, there is a significant difference between primary school teachers and pre-school teachers in favour of pre-school teachers.

The thoughts of pre-school teachers' on plans and practices to perform gains in the social development curriculum $(4,15)$ are higher than classroom teachers' thoughts of children achieving these gains $(3,40)$. As the significance value is $\mathrm{p}=$ $0,000<0,05$, there is a significant difference between primary school teachers and pre-school teachers in favour of pre-school teachers.

The thoughts of pre-school teachers' on plans and practices to perform gains in the psychomotor development curriculum $(4,38)$ are higher than classroom teachers' thoughts of children achieving these gains $(3,69)$. As the significance value is $\mathrm{p}=0,000<0,05$, there is a significant difference between primary school teachers and pre-school teachers in favour of pre-school teachers.

The thoughts of pre-school teachers' on plans and practices to perform gains in the self-care skills development curriculum $(4,45)$ are higher than classroom teachers' thoughts of children achieving these gains(3,53). As the significance value is $\mathrm{p}=0,000<0,05$, there is a significant difference between primary school teachers and pre-school teachers in favour of pre-school teachers.

When we look at the teacher's views on the realization levels of gains related to developmental areas, there is a significant difference was found in favour of pre-school teachers regarding all developmental areas. The table below shows the correlation analysis between the developmental areas. 
Table 15. The correlation analysis among developmental areas in the pre-school curriculum

\begin{tabular}{|c|c|c|c|c|c|c|}
\hline & & $\begin{array}{l}\text { Language } \\
\text { Development }\end{array}$ & $\begin{array}{l}\text { Cognitive } \\
\text { Development }\end{array}$ & $\begin{array}{l}\text { Social } \\
\text { Development }\end{array}$ & $\begin{array}{l}\text { Psychomotor } \\
\text { Development }\end{array}$ & $\begin{array}{l}\text { Self-Care } \\
\text { skills }\end{array}$ \\
\hline \multirow{2}{*}{ Language Development } & Cor. coefficient (r) & 1 & & & & \\
\hline & Significany $(\mathrm{p})$ & & & & & \\
\hline \multirow{2}{*}{ Cognitive Development } & Cor. coefficient $(\mathrm{r})$ &, $716(* *)$ & 1 & & & \\
\hline & Significany $(\mathrm{p})$ &, 000 & & & & \\
\hline \multirow{2}{*}{ Social Development } & Cor. coefficient $(\mathrm{r})$ &, $610(* *)$ &, $756(* *)$ & 1 & & \\
\hline & Significany $(\mathrm{p})$ &, 000 &, 000 & & & \\
\hline \multirow{2}{*}{ Psychomotor Development } & Cor. coefficient $(\mathrm{r})$ &, $547(* *)$ &, $686(* *)$ &, $676(* *)$ & 1 & \\
\hline & Significany $(\mathrm{p})$ &, 000 &, 000 &, 000 & & \\
\hline \multirow{2}{*}{ Self-Care Skills } & Cor. coefficient (r) &, $651(* *)$ &, $684(* *)$ &, $724(* *)$ &, $645(* *)$ & 1 \\
\hline & Significany $(\mathrm{p})$ &, 000 &, 000 &, 000 &, 000 & \\
\hline
\end{tabular}

** Correlation value at significance level of 0.01 is significant.

According to the correlation analysis above, all the correlation coefficients among the developmental areas are found as positive value and significance values are found as $p<0,05$. According to these results, there is a meaningful relationship and they have the same direction in the all developmental areas. When opinions on one of the developmental areas increase, other developmental areas are also affected and the increase is observed in the same direction.

In general, when answers given by participants to developmental areas were examined, there was a significant difference in favour of preschool teachers in all developmental areas between the views of preschool and classroom teachers. When we look at the answers given to the questionnaire items, we see that pre-school teachers find that the curriculum and the activities in the curriculum are adequate and they have no problems in implementation. When we look at the responses of classroom teachers, we can say that they have indicated children have achieved some gains, but they are not at the desired level.

\section{Discussions and Results}

Children are universal novices who only gradually develop the ability to perform at levels that are characteristic of adults. For example, over time children improve their ability to remember information (e.g., Kail \& Siegel, 1977), to comprehend and communicate effectively (e.g., Chapman, 1978; Chomsky, 1969; G1ucksberg, Krauss, \& Higgins, 1975), to solve problems (e.g., Inhelder \& Piaget, 1958), to accurately predict their own abilities to perform various tasks (e.g., Flavell \& Wellman, 1977), and so forth.

There has been a growing need for information on quality preschools and childcare programs in an age of growing numbers of preschool programs around the world, especially during the last two decades. International reports such as those issued by the World Health Organization and UNESCO documented the relationship between quality early childhood programs on children's health and success in school. Early childhood educators in the twentieth century were most interested in the nature of early childhood programs within their own state, region or nation. Toward the end of the century when perceptions became more globalized, there was a growing awareness of preschool programs in other countries. More importantly, interest was growing about the nature of these programs and developing countries trying to begin programs were seeking guidance on how to evaluate the quality of their programs (Wortham, 2013).

When the researches related to the subject are examined; in a research conducted by Öztürk (1995: 90), the language levels of the recipient and the expressive language of first year pupils having or not having preschool education were compared. As a result of the research, a meaningful difference was obtained in favour of pre-schooled learners about the recipient and expressive language skills. It was found that pre-school children had higher vocabulary, higher level of understanding language and using it than those who did not take pre-school education and so it was found that they were ready to begin primary education. Seçilmiş (1996: 193) had conducted a similar study called the study of language development of children, having or not having a pre-school education, between 36-72 months and it was found that there is a meaningful difference in favour of students attending pre-school. Thus, teacher awareness of some of the elements of language development is crucial. Demir (2010: 43) assessed whether the predicted cognitive developmental characteristics in the pre-school curriculum reflected the facts or not, and examined to what extent the cognitive developmental characteristics of children aged 36-60 months were realized. As a result, this study revealed that pre-school education and 2006 pre-school curriculum have a positive effect on cognitive development (perception, attention, problem solving, cause-effect relationship, etc.). Kol (2011: 55) did a similar study called "Cognitive and Language Development in Early Childhood". When the results of the study are examined, it was stated that the environment, full of rich stimulants, of the child provided positive contributions to the cognitive development. Özbek (2003: 118) has conducted a research. As a result of this research, it is determined that there is a difference between two 
groups of children and this difference is in favour of the children that have pre-school education. Başal (2005: 38) also conducted a research about similar topic. As a result of this research, it was found that six months of pre-school education provided more development in some subjects. This development was seen in some characteristics such as children's self-esteem, self-confidence, self-expression, and more interest in objects. Similar study results are in the same line with current research results. Tamkavas (2003: 55) found that pre-school education has a positive effect on these skills in a study of 5-6 year-olds' study of self-care skills according to gender and pre-school education. It has been seen that they are successful in matters such as personal hygiene, unattended dressing without taking help, classroom hygiene. Research findings also support current research results.

Given the diversity of young children in early care and education programs, it is unlikely that the field will or should come to consensus on the superiority of a single curricular model. Effective curricula rely on a balance between a clearly defined structure that impacts all children and flexibility that allows for individualization for children, families, and classrooms. Curriculum research must, therefore, discern the conditions under which certain curricula work best for certain children. Specifically, next generation research must examine which approaches produce educationally meaningful effects in which domains of development, for which children, under what social conditions, and with what kinds of professional preparation for teachers (Bertrand, 2012: 25-28; Karoğlu \& Ünüvar, 2017). Current government policies aspire to achieve better health outcomes for children through provision of health, social and education services for all, and progress in minimizing health and educational inequalities (Cowie, 2013).

The pre-school period is a critical time period for creativity of children and for developing it. Another important thing is creating an effective pre-school education equipped with rich stimulants that the child needs. Learning is a transactional experience mediated by the "funds of knowledge" of young children and families as well as multiple environmental contexts (Moll et al. 1992). Thus, the quality of these experiences and the settings in which they take place is essential for maximizing children's development. Young children's natural curiosity, interest, and self-confidence that they can discover the answers to their questions are a central component of their capacities to benefit from learning opportunities (Thompson 2002). It helps to equip children to share in the benefits of the society in which they live and to contribute effectively to that society's sustenance and evolution. It is essential to improve of the physical conditions of existing pre-school classes and to support materials. It should also provide opportunities for children to reach the highest level in these areas by creating appropriate activities for all developmental areas present review of research findings suggests that in-service training and seminars should be held frequently and teachers' participation should be ensured in order to improve the quality of the updated curriculum and to ensure their effective implementation. In addition to these, the family factor should not be forgotten and active participation in the education and training process should be ensured.

\section{References}

Abbott, D., Lundin, J., \& Ong, F. (2008). The California Preschool Learning Foundations (Volume 1). The California Department of Education. ISBN 978-0-8011-1681-0.

Association for Childhood Education International (ACEI). (2006). ACEI global guidelines assessment (2nd ed.). Olney: Author.

Başal, H. A. (2005). The Principal and Methods of Pre-school Education. İstanbul, Morpa Publishing

Bertrand, J. (2012). Preschool Programs: Effective Curriculum. Comments on Melhuish and Barnes, Kagan \& Kauerz, Schweinhart, \& Leseman. MA Teachers College, Topic Editor: Edward Melhuish, Columbia University, USA December 2012, 2nd ed., 25-28.

Bloom, L., \& Tinker, E. (2001). The intentionality model and language acquisition: Engagement, effort, and the essential tension. Monographs of the Society for Research in Child Development, 66(Serial No.267).

Bloom, L., Hood, L., \& Lightbown, P. (1974). Imitation in language development: If, when, and why. Cognitive Psychology, 6, 380-420. https://doi.org/10.1016/0010-0285(74)90018-8

Brown, R. W. (1973). A first language: The early stages. Cambridge, MA: Harvard University Press. https://doi.org/10.4159/harvard.9780674732469

Chaddock, L. (2012). The effects of Physical Activity on the Brain and Cognition During Childhood. (Doctoral dissertation). University of Illinois at Urbana-Champaingn, 1 and 2, US.

Chaddock-Heyman, L., Erickson, K. I., Voss, M. W., Knecht, A. M., Pontifex, M. B., Castelli, D. M., ... Kramer, A. F. (2013). The effects of physical activity on functional MRI activation associated with cognitive control in children: A randomized controlled intervention. Frontiers in Human Neuroscience, 7, 72.

https://doi.org/10.3389/fnhum.2013.00072 
Chapman, R. S. (1978). Comprehension strategies in children. In I. Kavanagh \& W. Strange (Eds.), Speech and language in the laboratory, school, and clinic. Cambridge, MA: MIT Press,

Chomsky, C. (1969). The acquisition of syntax in children from 5 to 10. Cambridge, MA: MIT Press.

Cowie, H. (2013). From birth to sixteen: children's health, social, emotional and linguistic development Routledge.

Demir, S. (2010). The comparison of 36-60 months children who take preschool education in terms of the characteristics of cognitive development (Unpublished thesis) Marmara University, İstanbul.

Espinosa, L. (2002). High Quality Preschool: Why We Need It and What It Looks Like. National Institute For Early Childhood Education Research, 1, 1-11.

Flavell, J. H., \& Wellman, H. M. (1977). In R. V. Kail \& J. W. Hagen (Eds.), Perspectives on the development of memory and cognition. Hillsdale, NJ: Erlbaum.

Glucksberg, S., Krauss, R., \& Higgins, E. T. (1975). The development of referential communication skills. In F. D. Horowitz (Ed.), Review of child development research (Vol. 4). Chicago: University of Chicago Press.

Inhe1der, B., \& Piaget, J. (1958). The growth of logical thinking from childhood to adolescence. New York: Basic Books. https://doi.org/10.1037/10034-000

Kachmar, S. (2008). Early Cihildhood Calssroom Quality and Preschool Learning Behaviors (Unpublished Doctoral's Thesis). Duquesne University, United States.

Kail, R. V., \& Siege1, A. W. (1977). The development of mnemonic encoding in children: From perception to abstraction. In R. V. Kail \& J. W. Hagen (Eds.), Perspectives on The Development of Memory and Cognition. Hillsdale, NJ: Erlbaum,

Karoğlu, H., \& Ünüvar, P. (2017). Children's development characteristics and social skills level of pre-school children Mehmet Akif Ersoy Üniversitesi Eğitim Fakültesi Dergisi ISSN:1302-8944 Year: 2017, 43, 231-254.

Kol, S. (2011). Cognitive Development and Language Development in Early Childhood. The Journal of SAU Education Faculty, 21(May 2011), 1-21.

Martin, M. (1999). Primary School Curriculum. Dublin: The Stationary Office.

Moll, L. C., Amanti, C., Neff, D., \& Gonzalez, N. (1992). Funds of knowledge for teaching: Using a qualitative approach to connect homes and classrooms. Theory into Practice, 31, 132-141. https://doi.org/10.1080/00405849209543534

Nicolosi, I., Harryman, F., \& Krescheck J. (1989). Terminology of Communication Disorders: Speech-LanguageHearing, 3rd ed. Baltimore: Williams and Wilkins.

Oğuzkan G., \& Oral, G. (1997). Preschool education (2. Edition) İstanbul.

Owens, R. E. Jr. (2008). Language Development: An Introduction, 7th ed. New York: Pearson Education.

Özbek, A. (2003). Okul Öncesi Eğitim Kurumlarına Devam Eden ve Etmeyen Çocukların İlköğretim Birinci Sinıfta Sosyal Gelişim Açısından Öğretmen Görüşüne Dayalı Olarak Karşılaş̧tırlması, (Unpublished thesis), Anadolu University, Eskişehir.

Öztürk, H. (1995). Okul Öncesi Eğitim Kurumlarına Giden Ve Gitmeyen Öğrencilerinin Alıcı Ve Ífade Edici Dil Düzeyleri. (Unpublished thesis), Gazi University, Ankara.

Rao, N., Sun, J., Wong, J. M. S., Weekes, B., Ip, P., Shaeffer, S., ... Lee, D. (2014). Early childhood development and cognitive development in developing countries: A rigorous literature review. Department for International Development.

Seçilmiş, S. (1996). Investigation of language development of preschool children who were attending preschool and were not (Unpublished thesis) Hacettepe University, Ankara.

Shulman, B. B., \& Singleton, N. C. (2010). Language Development: Foundations, Processes, and Clinical Applications. Chapter 2. Child Development. (Theresa E. Bartolotta and Brian B. Shulman). Jones \& Bartlett Publishers.

Tamkavas, E. (2003). 5-6 Yaş Çocuklarının Öz Bakım Becerilerinin Cinsiyet ve Okul Öncesi Eğitim Alma Durumuna Göre Incelenmesi. (Unpublished thesis), Selçuk University, Konya.

The Hong Kong Special Administrative Region Government (2006) Comments and suggestions on the Guide to the Pre-primary Curriculum. The Curriculum Development Council (CDC) of Hong Kong for Pre-primary Institutions. 
Thompson, R. A. (2002). The Roots of School Readiness in Social and Emotional Development, The Kauffman Early Education Exchange, 1, 8-29.

Thompson, R. W. (1996). Youth Sport Involvement in New Zealand: Issues, Images and Initiatives. FIEP Bulletin, 66(1), 22-34.

Timmons, B. W., Naylor, P. J., \& Pfeiffer, K. A. (2007). Physical activity for preschool children - how much and how? Applied Physiology, Nutrition and Metabolism, 32(Suppl), S122-S134. https://doi.org/10.1139/H07-112

Tomporowski, P. D., Davis, C. L., Miller, P. H., \& Naglieri, J. A. (2008). Exercise and Children's Intelligence, Cognition, and Academic Achievement. Educational Psychology Review, 20(2), 111-131. https://doi.org/10.1007/s10648-007-9057-0

Trudeau, F., \& Shephard, R. J. (2008). Physical education, school physical activity, school sports and academic performance. International Journal of Behavioral Nutrition and Physical Activity, 5, 5-10. https://doi.org/10.1186/1479-5868-5-10

United Nations Educational, Scientific and Cultural Organization (UNESCO). (2006). Strong foundations: Early care and education EFA global monitoring report: Strong foundation. Paris: UNESCO Publishing.

Wortham, S. C. (2013). Common characteristics and unique qualities in preschool programs: Global perspectives in early childhood education. Dordrecht: Springer. https://doi.org/10.1007/978-94-007-4972-6

\section{Copyrights}

Copyright for this article is retained by the author(s), with first publication rights granted to the journal.

This is an open-access article distributed under the terms and conditions of the Creative Commons Attribution license which permits unrestricted use, distribution, and reproduction in any medium, provided the original work is properly cited. 